\title{
Profitability of Cocoon Production in Ado-Ekiti, Ekiti State, Nigeria
}

\author{
Oluwayemisi G. E. Arowosoge ${ }^{1}$ \\ ${ }^{1}$ Department of Forestry, Wildlife and Fisheries Management, Ekiti State University, Ado-Ekiti, Nigeria \\ Correspondence: Oluwayemisi G. E. Arowosoge, Department of Forestry, Wildlife and Fisheries Management, \\ Ekiti State University, Ado-Ekiti, Nigeria. Tel: 234-803-355-2632. E-mail: yemisoge@yahoo.co.uk
}

Received: June 22, 2015 Accepted: July 16, 2015 Online Published: August 15, 2015

doi:10.5539/jas.v7n9p189 URL: http://dx.doi.org/10.5539/jas.v7n9p189

\begin{abstract}
This research is a case study which assesses profitability of Bombyx mori silkworms cocoon production in Ekiti State Sericulture Development Project Centre, Ado-Ekiti, Ekiti State, Nigeria. Structured questionnaire was administered on 31 respondents made up of 3 management staff, 20 farmers of mulberry and 8 cocoon producers. Data were collected on cost and revenue over a period of five year from 2009 to 2013. The collected data were analyzed using percentage mention, Gross Margin Ratio (GMR), Benefit Cost Ratio (BCR) and Rate of Return on Investment (RORI). The results show that investment on cocoon production was not profitable. The GMR obtained were abysmally low and ranged from $3.29 \%$ to $12.30 \%$. The RORI obtained was below the bank interest rate of $21 \%$. RORI ranged from $3.40 \%$ to $14.02 \%$ with an average of $9.26 \%$ at five years. The BCR was 1.10 after five years with 0.10 kobo as profit on every $\$ 1$ spent. Funding ranked $1^{\text {st }}$ with $90.3 \%$ mention as major problem militating against cocoon production. In order to solve the problems of fund, loan could be sourced from Agricultural Development Bank at low interest rate since the project is meant to generate revenue for the state.
\end{abstract}

Keywords: cocoon production, gross margin ratio, benefit cost ratio, rate of return on investment

\section{Introduction}

Silkworm cocoon is produced through the practice of sericulture which involves the cultivation of mulberry plants and rearing of silkworm with mulberry leaves for the production of cocoon which are reeled into raw silk. The cultivation of mulberry plants, the rearing of silkworm with mulberry leaves to produce cocoon as well as the reeling of cocoon to produce raw silk is a labour intensive practice (Srinivasa, Chengappa, Achoth, Reddy, \& Nagaraja, 2005). The cultivation of mulberry plants and rearing of silkworm are agro-forestry based, while the production of silk is industrial. These practices can generate huge employment. For instance, it has been observed that for every kilogram of raw silk produced, 12 people, mostly women are engaged in silk reeling, threading and weaving; fabrication of machines for both the small filature and the big time miller (Srinivasa et al., 2005; Dandin, Qadri, \& Krishnamoorthy, 2005; Prakasam \& Ravi, 2014). It is therefore suited for all developing countries like Nigeria where unemployment and under employment is a serious problem (Ayoade, Oyejide, \& Fayemi, 2014).

The production of silk originated in China, but in the early phase of the $18^{\text {th }}$ century, Japan was ruling the world silk market by producing $70 \%$ of world's total output (Vainker-Shelagh, 2004). From mid seventies, the Japanese silk production started declining and Chinese silk production increased steadily to bridge the gap created by Japan (Vainker-Shelagh, 2004; Data \& Nanavaty, 2007). China and India have since been the two main producers of the world silk contributing about $60 \%$ of the world production each year (U.S. Geological Survey, 2007; Kumaresan, Geetha, Rajadurai, Selvaraju, \& Jayaram, 2008). From the report of Mattigatti, Veerabhadrappa, and Renukarya (2009), China produces 93100 Metric tonnes of raw silk in year 2006 and controls the international silk trade followed by India with 16525 Metric tonnes in the same year.

The economic contribution of sericulture has not only been noted in countries like China, Japan and India but also in Korea, Brazil, Russia, Italy and France, where sericulture has become one of the most important cottage industries. In these countries, the practice of sericulture provides a year - round income when compared to crop production which has seasonal income (Srinivasa et al., 2005; Dandin et al., 2005; Kumaresan et al., 2008). The employment opportunities provided by sericulture cannot be over-emphasized. For instance in China, sericulture employed 20 million households who cultivated 2 million hectares of mulberry in 22 provinces out of 25 
provinces of China, while there were also 1000 silk factories with 2.4 million reeling machines employing a million workers (Qiu, 2005). In India, sericulture is an agricultural based industry that has provided gainful employment for millions of people with an indirect effect of about 25 per cent of farm income (Mattigatti \& Iyengar, 1995).

Although, the production of silk garments in Nigeria primarily by Yoruba people dates back to $12^{\text {th }}$ century AD where cocoon used for weaving by men were obtained from the forest trees such as Triplochyton sclerexylon (obeche) (Clarke, 1998; Olajide, Joseph, Babatunde, Obafemi, \& Ife, 2009); however, at present the practice of sericulture is at low ebb in the country. The rearing of silkworm for cocoon and silk production is relatively new and it is still at the infant stage (Adeduntan, 2013). In Ekiti State, sericulture is being practiced and managed only by the State Government at the Sericulture Development Project Centre, Ado-Ekiti which was established in 1998. From the foregoing, it is clear that in Nigeria, there is lack of awareness on the value and roles that sericulture could contribute to the economy of the country. It therefore becomes desirable and justifiable to evaluate the profitability of this project. Moreso, that literature reviews have shown that reliable and dependable income accrues to people who are involved at the different stages (mulberry, cocoon and silk) of production. This research is therefore a case study which assesses the profitability from cocoon production while identifying the problem militating against its production at the project centre.

\section{Cocoon Production Process}

The production of cocoon starts with hatching of silkworms Bombyx mori eggs. The eggs are incubated for 9 days for hatching. As they hatch, the tiny silkworms are carefully distributed to wooden rearing trays to be fed with fresh tender mulberry leaves from the apex of the plant several times a day. The leaves are chopped into various sizes ranging from $0.5 \mathrm{~cm}$ to $1.0 \mathrm{~cm}$ for easy feeding by the young silkworms. As the silkworms develop, the leaves sizes are increased to a range of between $1.5 \mathrm{~cm}$ and $2.0 \mathrm{~cm}$. The worms are protected from predators by wrapping the trays with small mesh. As the silkworms increase in size, the colonies are divided into more trays to prevent overcrowding and ensure efficient feeding.

The depreciation of food consumption by the worms signals the beginning of cocoon spinning. This is noticed after about 22 days of rearing. In order to make the cocoons uniform in shape and for easy harvesting, the silkworms are picked into a wooden scaffolding for cocoon spinning which takes about 2 days. Immediately after spinning, the cocoons are harvested, thus a complete cycle after hatching of silkworm eggs to complete cocoon production takes about 24 days.

Three hectares of land were cultivated with two mulberry species between 1999 and 2009 at the sericulture centre. This was necessary to ensure a ready supply of mulberry leaves as silkworms most favourite food is the mulberry leaves. The species planted are Morus alba (white mulberry) and Morus nigra (Black mulberry). However, about 10 - 12 species have been identified worldwide out of which Morus alba, Morus tatarica, Morus nigra and Morus rubra are mostly used (Ombrello, 2010).

\section{Methodology}

\subsection{Study Area}

This research work was carried out at Sericulture Development Project Centre, Ado-Ekiti in Ekiti-State. The project centre was established in 1998 while the State was carved out from the former Ondo-State on the $1^{\text {st }}$ of October, 1996. Ekiti-State is one of the six States constituting the South-West Geo-political zone of Nigeria. Although some parts of the State are fairly urbanized, the majority of the population still lives in the rural areas. The State shares boundaries with Kwara-State in the Northern part of the State, Osun-State in the Western and Ondo-State in the South Eastern part. The State is made up of 16 Local Government Areas with a population of 2 384212 (National Population Commission [NPC], 2007). Temperature in the State ranges between $21{ }^{\circ} \mathrm{C}$ to 28 ${ }^{\circ} \mathrm{C}$ while humidity varies between 35 and $80 \%$ (UniQue Solutions Int'l Ltd., 2015). Rain forest exists in the South while guinea savannah occupies the Northern part. About $70 \%$ of the entire population of Ekiti State is actively engaged in farming as their main occupation.

\subsection{Sampling Technique}

The whole population of the cocoon producers and mulberry farmers that are involved in sericulture in the project centre was studied. Preliminary survey showed that 20 mulberry farmers and 8 cocoon producers are involved in sericulture at the project center.

\subsection{Data Collection}

Data were collected through the use of structured questionnaire, discussion and personal interviews. Secondary 
data were also collected from the existing records of sericulture project in Ekiti-State. Three sets of questionnaire were structured using open-ended and guided questions with options. First set was administered on the top management of sericulture project in Ekiti-State. The second set was administered on staff members who were engaged in rearing of silkworms and harvesting of cocoon. The third set was administered on farmers who were engaged in mulberry leaves production. The study made use of data from 31 respondents consisting of 3 management staff, 20 farmers of mulberry, most of who were casual workers and 8 cocoon producers. Data collected covered a period of five year from 2009 to 2013.

\subsection{Model Specification for Data Analysis}

The profitability analysis was carried out using Gross Margin Ratio (GMR) Benefit Cost Ratio (BCR) and Rate of Return on Investment (RORI). Gross margin ratio is the ratio of gross profit of a business to its revenue. It is a profitability ratio measuring what proportion of revenue is converted into gross profit. That is revenue less variable cost of goods sold (Nelson, 2008). The formula for GMR is as expressed below:

$$
\begin{gathered}
G M R=T R-T V C / T R \\
T R=P \times Q \\
T V C=P \times X_{1}+P \times X_{2}+\ldots P \times X_{n} \\
G M R=P \times Q-\frac{P \times X_{1}+P \times X_{2}+\ldots P \times X_{n}}{P \times Q}
\end{gathered}
$$

Where, $G M R=$ Gross margin ratio; $T R=$ Total revenue; $P=$ Price; $Q=$ Quantity produced; $X=$ Production input; $T V C=$ Total variable cost.

The Benefit cost ratio is the ratio of discounted cost to discounted return. The decision for BCR is to adjudge the enterprise efficient if $\mathrm{BCR}$ is equal 1 or greater than 1 . The higher the ratio, the higher the return per Naira invested (Gittinger, 2012). This ratio was obtained by dividing the present worth of the revenue (discounted benefit) with the present worth of the cost (discounted cost). Mathematically it is expressed as:

$$
B C R=\frac{\sum_{t=1}^{t=n} \frac{B_{t}}{(1+r)}}{\sum_{t=1}^{t=n} \frac{C_{t}}{(1+r)^{t}}}
$$

Where, $B_{t}=$ Benefit $/$ Revenue in each year; $C_{t}=$ Cost in each year; $r=$ Discount (interest) rate; $t=1,2, \ldots \mathrm{n}$; $n=5$ years.

Rate of Return on Investment (RORI) was used to determine how much was realized on the money invested (Arene, 1998). It is expressed mathematically as:

$$
\begin{gathered}
R O R I=\frac{\pi}{T C} \times \frac{100}{1} \\
\pi=T R-T C \\
T C=P \times X_{1}+P \times X_{2}+\ldots P \times X_{n}+T F C \\
\pi=P \times Q-\left(P \times X_{1}+P \times X_{2}+\ldots P \times X_{n}+T F C\right)
\end{gathered}
$$

Where, $\pi=$ Profit; $T C=$ Total Cost; $T F C=$ Total fixed cost; TR, $P, Q, T V C$ and $X$ are as defined in Equation (1).

Percentage mention was used to rank the problems militating against the production of cocoon. \% mention is as stated below:

$$
\frac{N T V M}{N I C} \times \frac{100}{1}
$$

Where, $N T V M=$ No of time a variable was mentioned; $N I C=$ No of interviewed conducted.

\section{Results and Discussion}

\subsection{Profitability Analysis of Cocoon Production}

\subsubsection{Estimated Revenue}

The revenue for the 5 years of study was obtained by estimating the products of the average selling price of cocoon per $\mathrm{kg}$ and the quantity of cocoon produced per annum. The quantity of cocoon produced per annum varied from $4870.56 \mathrm{~kg}$ with an average of $541.17 \mathrm{~kg}$ per month in 2009 to $5557.70 \mathrm{~kg}$ with an average of $617.5 \mathrm{~kg}$ per month in 2013 (Table 1). Respondents were of the opinion 
that higher quantity of cocoon could be produced if fund was available. They claimed production could be up to 9 times (from march to November) in a year since a cycle is about 24 days while $2000 \mathrm{~kg}$ of cocoon could be produced in a month.

The selling price of cocoon was $\$ 550$ (\$3.29) for the first 2 years and later increased to $\$ 600$ (\$3.59) from year 2011 to 2013. At the international market, the price of China cocoon ranges between $\$ 719.40$ (\$4.31) and $\$ 935.00$ (\$5.60) per kg. For the five years considered, the revenue obtained ranged from $\$ 2678808.00$ in 2009 to $\$ 3346200.00$ in 2013 (Table 1).

Table 1. Revenue from cocoon production

\begin{tabular}{llllll}
\hline \multirow{2}{*}{ Variable } & \multicolumn{5}{c}{ Year } \\
\cline { 2 - 6 } & $\mathbf{2 0 0 9}$ & $\mathbf{2 0 1 0}$ & $\mathbf{2 0 1 1}$ & $\mathbf{2 0 1 2}$ & $\mathbf{2 0 1 3}$ \\
\hline Cocoon $(\mathrm{Kg})$ & 4870.56 & 5112.16 & 4980.41 & 5129.58 & 5577.00 \\
Selling Price/Kg $(N)$ & 550 & 550 & 600 & 600 & 600 \\
Total Revenue & $\mathbf{2 6 7 8 ~ 8 0 8 . 0 0}$ & $\mathbf{2 8 1 1 6 8 8 . 0 0}$ & $\mathbf{2 9 8 8 2 4 6 . 0 0}$ & $\mathbf{3 0 7 7} \mathbf{7 4 8 . 0 0}$ & $\mathbf{3 3 4 6} \mathbf{2 0 0 . 0 0}$ \\
\hline
\end{tabular}

Note. $\$ 1=167$.

\subsubsection{Cost Components for Cocoon Production}

The cost components used in estimating the gross margin ratio for the production of cocoon are the variable cost. These include cost of eggs, nylon, chemicals, fuel, cutlasses, rent on land, rent on building, salary, contingency, depreciation values of wooden structure, deep freezer, mower cutter, spraying machine, incubator, wire mesh, net and containers (Table 2). Depreciation of cutlasses was not carried out since the mulberry farmers complained of not having enough cutlasses for cultivating the farm; in most cases they were given one cutlass per annum which has no value at the end of each year. The variable cost of wooden structures, deep freezer, mower cutter, spraying machine, incubator, wire mesh, net and containers were calculated using straight line depreciation method to obtain the actual amount spent per year from the fixed cost item.

\subsubsection{Gross Margin Ratio (GMR)}

The GMR on cocoon production at the Sericulture Centre in Ado-Ekiti as presented in Table 2 were abysmally low and ranged from $3.29 \%$ to $12.30 \%$. The highest GMR of $12.30 \%$ was obtained in year 2010 while the least, $3.29 \%$, was obtained in year 2012. GMR is a good indication of how profitable a business is at the most fundamental level, on how efficiently a company is using its resources, materials, and labour. Higher values indicate that more kobo are earned per naira of revenue which is favorable because more profit will be available to cover non-production costs, while GMR tends to remain stable over time (Nelson, 2008). The trend obtained for GMR in this study showed that GMR increased from 2009 to 2010 and then declined from 2011 to 2012 before increasing in 2013. This trend showed that there were some underlining problems in the production of cocoon in the study area. Nelson (2008) is of the opinion that significant irregularities or sudden variations might be a potential sign of financial fraud, accounting irregularities, or problems in the business. 
Table 2. Revenue, cost and GMR for cocoon production

\begin{tabular}{|c|c|c|c|c|c|}
\hline \multirow{2}{*}{ Variables } & \multicolumn{5}{|c|}{ Year } \\
\hline & 2009 & 2010 & 2011 & 2012 & 2013 \\
\hline A. REVENUE (N) & 2678808 & 2811688 & 2988246 & 3077748 & 3346200 \\
\hline \multicolumn{6}{|l|}{ B. Cost $(\#)$} \\
\hline Eggs & 330000 & 344000 & 462000 & 550000 & 601100 \\
\hline Nylon & 14640 & 14640 & 18750 & 18750 & 18750 \\
\hline Chemicals (Herbicides and Pesticides) & 45140 & 48714 & 52850 & 68714 & 72850 \\
\hline Fuel & 320000 & 330000 & 380000 & 382000 & 380000 \\
\hline Salary & 1240000 & 1240000 & 1300000 & 1340000 & 1340000 \\
\hline Cutlasses & 7200 & 7200 & 10500 & 10500 & 10500 \\
\hline Land (Rent) & 80000 & 100000 & 120000 & 140000 & 160000 \\
\hline Building (Rent) & 200000 & 240000 & 280000 & 320000 & 360000 \\
\hline Depreciation on wire mesh, net and container & 12000 & 12000 & 12000 & 12000 & 12000 \\
\hline Depreciation on Incubator & 20000 & 20000 & 20000 & 20000 & 20000 \\
\hline Depreciation on Wooden Structure & 25000 & 25000 & 25000 & 25000 & 25000 \\
\hline Depreciation on Deep Freezer & 20000 & 20000 & 20000 & 20000 & 20000 \\
\hline Depreciation on Spraying machine & 10000 & 10000 & 10000 & 10000 & 10000 \\
\hline Depreciation on Mower & 30000 & 30000 & 30000 & 30000 & 30000 \\
\hline Sub-Total & 2353980 & 2441554 & 2741100 & 2946964 & 3060200 \\
\hline $1 \%$ Contingency & 23540 & 24416 & 27411 & 29470 & 30602 \\
\hline Total Cost (N) & 2377520 & 2465970 & 2768511 & 2976434 & 3090802 \\
\hline Gross Margin & 301288 & 345718 & 219735 & 101314 & 255398 \\
\hline Gross Margin Ratio (\%) & 11.25 & 12.30 & 7.35 & 3.29 & 7.63 \\
\hline
\end{tabular}

Note. $\$ 1=\$ 167$.

\subsubsection{Benefit Cost Ratio (BCR) and Rate of Return on Investment (RORI).}

The results of BCR and RORI used to evaluate the profit on cocoon production at the Sericulture Centre in AdoEkiti are presented in Table 3. The result shows that at the actual cost of production of $21 \%$ discount rate, the $\mathrm{BCR}$ was 1.10. This shows that the business just break even after five years with 0.10 kobo as profit on every $\$ 1$ spent (Gittinger, 2012). The RORI on cocoon production ranged from $3.40 \%$ to $14.02 \%$. The highest RORI of $14.02 \%$ was obtained in year 2010 while the least, $3.40 \%$, was obtained in year 2012 with an average of $9.26 \%$ at five years. Based on the prevailing bank interest rate of $21 \%$, the RORI obtained shows that the investment was not profitable because the RORI from 2009 to 2013 on cocoon production could not pay the bank interest rate of $21 \%$. The results of BCR and RORI further confirm the low GMR obtained which showed that there were underlining problems in the production of cocoon in the study area. This is because cocoon production has been found to be highly profitable in countries such as India and china (Dandin et al., 2005; Srinivasa et al., 2005).

A major problem that was responsible for the non profitability of cocoon production at Ekiti-State Sericulture Development Project Centre, Ado-Ekiti is production at abysmally low level due to lack of fund for running expenses. Fund was not always released by the State Government for the sericulture project as at when due. When fund was not available, the farmers and the cocoon producers who were casual workers were often laid off only to be re-engaged when fund was available to pay their salaries. This problem used to result in the death of silkworms that are reared for cocoon production due to poor feeding and thus reducing the quantity of cocoon produced. 
Table 3. Benefit cost ratio analysis and rate of return on investment

\begin{tabular}{|c|c|c|c|c|c|c|c|}
\hline Year & Discount rate & $\operatorname{Cost}(\mathrm{N})$ & $\begin{array}{l}\text { Revenue/Benefit } \\
\text { (®) }\end{array}$ & Profit (N) & $\begin{array}{l}\text { Discounted } \\
\text { Cost (\#) }\end{array}$ & $\begin{array}{l}\text { Discounted } \\
\text { Revenue (\#) }\end{array}$ & RORI (\%) \\
\hline 1 & 0.826446 & 2377520 & 2678808 & 301288 & 1964892 & 2213891 & 12.67 \\
\hline 2 & 0.683013 & 2465970 & 2811688 & 345719 & 1684290 & 1920421 & 14.02 \\
\hline 3 & 0.564474 & 2768511 & 2988246 & 219735 & 1562752 & 1686787 & 7.94 \\
\hline 4 & 0.466507 & 2976434 & 3077748 & 101314 & 1388528 & 1435792 & 3.40 \\
\hline \multirow[t]{3}{*}{5} & 0.385543 & 3090802 & 3346200 & 255398 & 1191638 & 1290105 & 8.26 \\
\hline & & & & Total & 7792101 & 8546996 & 46.29 \\
\hline & & & & $\mathrm{BCR}=1.10$ & & Mean RORI & $=9.26$ \\
\hline
\end{tabular}

\subsection{Problems Militating Cocoon Production}

The problems confronting cocoon production in the study area are as presented in Table 4. Inadequate funding ranked $1^{\text {st }}$ with $90.32 \%$ mention. This was followed by inadequate manpower with $77.42 \%$ mention, while lack of training ranked $3^{\text {rd }}$ with $58.06 \%$ mention. Disease infestation of silkworm and inadequate land for mulberry cultivation ranked $4^{\text {th }}$ and $5^{\text {th }}$ with percentage mention of 51.61 and 48.39 respectively. These are the major problems that could be responsible for the low and irregular trend in the revenue obtained from the production of cocoon.

Table 4. Ranking of problems militating against cocoon production

\begin{tabular}{lllll}
\hline S/N & Problems & No of time Mentioned & $\%$ Mention & Rank \\
\hline 1. & Inadequate Funding & $28(31)$ & 90.32 & $1^{\text {st }}$ \\
2. & Inadequate manpower & $24(31)$ & 77.42 & $2^{\text {nd }}$ \\
3. & Lack of training & $18(31)$ & 58.06 & $3^{\text {rd }}$ \\
4. & Disease Infestation of silkworm & $16(31)$ & 51.61 & $4^{\text {th }}$ \\
5. & Inadequate land for mulberry cultivation & $15(31)$ & 48.39 & $5^{\text {th }}$ \\
\hline
\end{tabular}

\section{Conclusion and Recommendation}

This study has shown that cocoon production at Ekiti-State Sericulture Development Project centre Ado-Ekiti was not profitable because the returns could not offset the cost of production. The GMR obtained was abysmally low. The RORI obtained from 2009 to and 2013 were below the prevailing bank interest rate of $21 \%$, while the BCR could only break even after 5years with 0.10 kobo as profit on every $\$ 1$ spent. Major problems militating against the profitability of cocoon production include inadequate and untimely release of fund; inadequate manpower and training.

In order to make cocoon production profitable as it is in other countries such as China and India, the problems confronting the production of cocoon should be solved. Since the project is meant to generate revenue for the State, loan could be sourced from Agricultural Development Bank at low interest rate to prevent inadequate and untimely funding. The project could also be financed by the Small and Medium Enterprises Development Agency of Nigeria (SMEDAN). There is also the need to train the management staff that are involved in the production of cocoon. If cocoon production is found profitable in Ekiti State, it will go a long way in encouraging private enterprises in its production, creating employment while reducing poverty. The aforementioned are remarkable economic growth that could help in meeting the Millennium Development Goal (MDG) of reducing poverty by 2015 which has not been realistic.

\section{References}

Adeduntan, S. A. (2013). Nutritive Effects of Leaf Position of Mulberry Plant: Morus alba on Silkworm Bombyx mori L. Performance. Advances in Life Sciences, 3(2), 23-27.

Arene, C. J. (1998). Introduction to the Economic Analysis of Projects in Tropical Agriculture (p. 45). Falludu Publishing Company, Nsukka, Nigeria. 
Ayoade, F., Oyejide, N. E., \& Fayemi, S. O. (2014). Isolation, Identification, Antibiogram and Characterization of Bacterial Pathogens of the Silkworm, Bombyx mori in South- West Nigeria. Journal of Biological Sciences, 14(6), 387-402. http://dx.doi.org/10.3923/jbs.2014.425.430

Clarke, D. (1998). Colonial intervention and indigenous responses: The introduction of the European broad loom weaving in Oyo Town. Kurios Afr., 2, 201-209.

Dandin, S. B., Qadri, S. M. H., \& Krishnamoorthy, T. (2005). Comparative Economics of Sericulture with major cash crops in Erode District of Tamil Nadu (pp. 233-236). The 20th Congress of the International sericultural Commission held at Bangalore.

Darias-Martin, J., Lobo-Rodrigo, G., Diaz-Diaz, E., \& Hernandez-Cordero, A. (2003). Alcoholic beverages obtained from black mulberry. Journal of Food Technology, 41(2), 173-176.

Data-Rafat, K., \& Nanavaty-Mahesh. (2007). Global Silk Industry: A Complete Source Book. Ashish Publishing House Corporation New Delhi.

Fazaeli, M., Hojjatpanah, G., \& Emam-Djomeh, Z. (2011). Effects of heating method and conditions on the evaporation rate and quality attributes of black Mulberry (Morus nigra) juice concentrate. Journal of Food Science and Technology, 50(1), 35-43. http://dx.doi.org/10.1007/s13197-011-0246-y

Gittinger, J. P. (2012). Economic Analysis of Agricultural Project (4th ed.). Published by Ermy August Rush.

Jaiyeola, V., \& Adeduntan, S. A. (2002). Sericulture in Ondo State: A means of alleviating rural poverty in forestry and challenges at sustainable livelihood (pp. 202-207). Proceeding of 28th Annual Conference of the Forestry Association of Nigeria held in Akure, Ondo State.

Kim, Y. S., Jeong, D. Y., \& Shin, D. H. (2008). Optimum fermentation conditions and fermentation characteristics of Mulberry (Morus alba) Wine. Korean Journal of Food Science and Agricultural Sciences, 40(1), 5-9.

Kumaresan, P., Geetha, D., Rajadurai, S., Selvaraju, N. G., \& Jayaram, H. (2008). Performance of Large Scale Farming in Sericulture-An Economic Analysis. Indian Jn. of Agric. Econ., 63(4), 4-18.

Mattigatti, R., \& Iyengar, M. N. S. (1995). Role of different agricultural enterprises in agri-business with special reference to sericulture. Indian J. Seri., 33, 163-165.

Mattigatti, R., Veerabhadrappa, B. P., \& Renukarya, C. K. (2009). Yield gap in Sericulture in Karnataka - An Economic Analysis. Karnataka J. Agric. Sci., 22(5), 1046-1050.

National Population Commission. (2007). Nigeria's Census Summary, 2007 from the office of National Population Commission, Abuja, Nigeria. Retrieved September 15, 2014, from http://www.nigeriannews.com

Nelson, L. S. (2008). QuickBooks 2008 All-in-One Desk Reference for Dummies. Published by Willey Publishing Inc. Retrieved September 10, 2014 from https://books.google.com.ng/books?id=nznYrHHF22IC $\& \mathrm{pg}=\mathrm{PA} 370 \& \mathrm{dq}=$ calculation + profitability + ratio

Olajide, M. D., Jide, A. O., Joseph, A. B., Babatunde, A., Obafemi, J., \& Ife, I. (2009). Aso-oke production and use among Yoruba of Southwestern Nigeria. J. Pan Afr. Stud., 3, 55-72.

Ombrello, T. (2010). The mulberry Tree and Its silkworm connection. Retrieved January 5, 2014, from http://faculty.ucc.edu/biology.ombrello/pow/mulberrytree.htm

Prakasam, K., \& Ravi, G. (2014). Sericulture - An Ideal Enterprise for Sustainable Income in Erode District of Tamil Nadu. Language in India, 14(9), 10-19.

Qiu, L. D. (2005). China's Textile and Clothing Industry. Retrieved January 25, 2014, from http://s3.amazonaws.com/zanran_storage/www.bm.ust.hk/ContentPages/18112599.pdf

Srinivasa, G., Chengappa, P. G., Achoth, L., Reddy, K., \& Nagaraja, G. N. (2005). Optimum Cropping Pattern for Sericulture-dominant Farms in Southern Dry Zone of Karnataka. Agricultural Economics Research Review, $18,117-132$.

U.S. Geological Survey. (2007). Area Reports International. Asia and the Pacific-Geological Survey Mineral Yearbook (Vol. 3, p. 218).

UniQue Solutions Int'l Ltd. (2015). Retrieved January 10, 2015, from http://www.ekiti.com/AboutEkiti/aboutekiti.htm 
Vainker-Shelagh. (2004). Chinese Silk: A Cultural History (p. 20). Rutgers University Press.

\section{Copyrights}

Copyright for this article is retained by the author(s), with first publication rights granted to the journal.

This is an open-access article distributed under the terms and conditions of the Creative Commons Attribution license (http://creativecommons.org/licenses/by/3.0/). 